\title{
O SUJEITO NA GEOGRAFIA: UMA PROPOSTA PARA SE PENSAR O ESPAÇO POR MEIO DE DIFERENTES PRISMAS
}

\author{
Eliseu Savério Sposito \\ Universidade Estadual Paulista (UNESP) \\ Departamento de Geografia, Presidente Prudente, SP, Brasil \\ eliseu.sposito@unesp.br \\ Késia Anastácio Alves da Silva \\ Universidade Estadual Paulista (UNESP) \\ Departamento de Geografia, Presidente Prudente, SP, Brasil \\ kesia.anastacio@unesp.br
}

\begin{abstract}
RESUMO
Pensar o sujeito, na Geografia, é uma possibilidade que apresentamos, por meio de sua relação com o objeto, o espaço e em sua potência conceitual com o território e lugar. A partir dessas referências, os conceitos de horizonte geográfico e geograficidade surgem como meio e condição para leitura do sujeito. O texto, esboçado como uma proposta interpretativa, tem análise do percurso do sujeito sociológico ao sujeito geográfico, passando por sua relação com o espaço, o território e o lugar, indo na direção de uma interdisciplinaridade em busca de argumentos na Sociologia e na Antropologia, principalmente, como forma de diálogo para trazer, para a Geografia, diferentes leituras do espaço e do território.
\end{abstract}

Palavras chave: Pensamento geográfico. Espaço. Sujeito.

\begin{abstract}
Thinking of the subject, in Geography, is a possibility we present through its relation to the object, the space in its conceptual power and territory. From those references, it arises the concepts of geographic horizon and geographicity as means and condition to enable the subject reading. The drafted text as an interpretative proposal, has an analysis of the sociological subject's path to the geographic subject, through its ratio to space, territory and place, moving towards interdisciplinary in search for arguments in Sociology and Anthropology, mainly as a form of dialogue and bring into Geography different readings about space and territory.
\end{abstract}

Key words: Geographical thought. Space. Subject.

\section{UM ESBOÇO DA PROPOSTA}

A proposta deste texto é, a partir da análise de escritos de vários autores que enfatizam o papel do sujeito nas ciências sociais, relacioná-lo com o objeto da ciência geográfica, o espaço. Antes da empiricização do sujeito e do espaço, fazemos uma interlocução com a Sociologia para trazer, para a Geografia, a possibilidade de articular o sujeito com diferentes dimensões e recortes, com suas originalidades, para valorizar a dimensão humana na Geografia. Colocar em evidência conceitos polissêmicos e enraizados na tradição descritiva da Geog rafia é sempre um risco, mas necessário. E é com essa intenção que vamos esboçar o diálogo proposto.

O caminho do diálogo foi construído a partir das possibilidades de pensar o sujeito em relação a diferentes conceitos da Geografia (espaço, lugar, território) para chegar à sugestão de se desenvolver, como nova perspectiva para seu entendimento, as noções de horizonte geográfico e de geograficidade. A relação entre conceitos bastante estudados e a proposição de outros que aparecem neste texto não deve ser vista como uma guinada a novidades abstratas ou como anotações interdisciplinares ecléticas, mas por meio da leitura de diferentes contribuições que trazem elementos para se entender o papel do sujeito em uma visão geográfica do mundo por meio do espaço, lugar e território e pela relação sujeito-objeto.

Antes de explicitar os pares dialéticos que permeiam este texto, há alguns argumentos que precis am ser revelados sobre o sujeito, em específico sobre o sujeito evidenciado no fazer geográfico. Para

Caminhos de Geografia Uberlândia-MG $\quad$ v. 22, n. $82 \quad$ ago./2021 $\quad$ p.173-190 Página 173


Lima (2019), o "sujeito privilegiado pela geografia é, em termos gerais, o homem", mas "um homem abstrato, por vezes estatístico e atópico", e falta enfocar um "homem de existência concreta, porque singular" (p. 13). Para o autor, a concretude do sujeito na geografia "deriva, portanto, de sua corporeidade, o meio no curso do qual ele se abre para a espacialidade" (p. 14).

É neste contexto que este texto evocará o sujeito geográfico, aquele que pela experiência e por existir como ente corporificado que pensa, por estar "direta ou indiretamente enredado nos objetivos, inquietações, questões e problemas geográficos", ora como agente, ator, individuo em suas mais diversas formas de manifestações, "na qualidade de um corpo político (territorializado), passível de empoderamentos e interditos, e implicado na objetividade geográfica, o que evoca a necessidade de compreender tal relação como um modo de ser dos homens e mulheres segundo uma geograficidade, o modo de ser ou de existir geográfico da realidade em geral” (LIMA, 2019, p.14).

Pensamos o sujeito não apenas pelo espectro homem-meio, relação esta que o indivíduo ${ }^{1}$, não mais na qualidade de sujeito, apenas "restringe o objeto a um reflexo de suas subjetividades" (LIMA, 2015, p.2). Não se trata de reconhecer a qualidade criativa ou passiva do individuo na produção do objeto geográfico o espaço, isto é, reconhecer o fator antrópico ou a humanidade do indivíduo (LIMA, 2014). Mas se trata de reconhecer "o sujeito enredado nos fenômenos geográficos", aquele que possui como qualidade a capacidade de ser "agente transformador do espaço enquanto uma condição prática de sua existência material e de sua consciência" (LIMA, 2014, p.2). Tal como Lima (2014, p.2), "é o caráter transformador do homem, o que lhe qualifica como um sujeito ativo, que interessa-nos sublinhar".

Em termos de estrutura, este artigo está em organizado em três grandes partes. Na primeira, além de debatermos a relação entre sujeito e objeto, apresentamos uma breve discussão do que vem a ser o sujeito nas ciências sociais e na geografia. Após esta breve aproximação do sujeito enquanto conceito geográfico, iremos - através de pares dialéticos (sujeito e espaço, sujeito e lugar, sujeito e território), enfatizar o papel deste conceito na ciência geográfica. Por fim, discorreremos sobre formas de empirização do sujeito no fazer geográfico, estas possibilidades de leitura serão realizadas através de duas categorias: o horizonte geográfico e a geograficidade, com os devidos cuidados de sua contextualização e "obediência" à nossa orientação metodológica.

\section{SUJEITO E OBJETO}

Antes de adentrarmos nas discussões sobre o que é o sujeito e sua relação dialética com os conceitos de espaço, lugar e território, cabe tecer algumas considerações sobre a relação sujeito e objeto. Ela se dá quando utilizamos o método científico, seja ele de orientação dialética, fenomenológica ou hipotético-dedutiva ou, ainda, seja pela combinação de características desses métodos em uma abordagem eclética.

É preciso destacar que não cabe aqui expor longas argumentações sobre o método ${ }^{2}$ mas cabe trabalhar, um pouco, sua relação com o objeto. O que é o objeto? Trata-se da designação daquilo que é o foco de uma pesquisa, aquilo que é eleito pelo pesquisador como elemento da investigação. O pesquisador, nessa relação, torna-se o sujeito e o objeto é o foco de seu estudo. Mas a relação que parece uma simples equação binária, não pode ser assim enfocada. Há uma série de advertências que precisamos lembrar para não parecer que a simplificação torna a explicação mais fácil.

Em primeiro lugar, o método não pode ser apreendido, praticado, em outros termos, servir de orientação para a pesquisa, em termos disciplinares. Embora haja incontáveis textos que atrelem o método a uma disciplina, essa atitude é redutora e não ajuda para a produção do conhecimento. Não há método geográfico, método sociológico etc., que são adjetivados por uma disciplina ou seg mento de uma ciência.

Em segundo lugar, não comungamos com proposições que tornam o método algo vago, indistinto e propriedade de uma pessoa. Por exemplo, o que afirma Chauí (1986), não auxilia na compreensão do método como algo fundamental para a ciência como intermediação necessária para a produção do

1 O conceito de indivíduo trabalhado neste artigo será discorrido ao longo do texto.

2 Para maiores detalhes sobre o método, v. SPOSITO, Eliseu S. Geografia e Filosofia. São Paulo: Editora UNESP, 2004. 
conhecimento. Para ela, o método tem "sentido vago, porque todos os filósofos possuem um méto do ou o seu método, havendo tantos métodos quanto filósofos". Mas quando trata de maneira dif erente, acreditamos ser mais incisiva na afirmação: "sentido preciso, porque o bom método é aquele que permite conhecer verdadeiramente o maior número de coisas com o menor número de regras" (p. 28). É o sentido preciso que precisamos incorporar no plano abstrato (no nível do pensamento) e no plano concreto (como instrumento que auxilie no estudo da relação sujeito-objeto).

O respeito ao método auxilia na compreensão do que são categorias e conceitos e na distinção de seus elementos fundamentais (lei, doutrina, ideologia) porque eles vão distinguir a força das teorias construídas segundo as diferentes orientações que emergem com o seu uso.

São esses cuidados, de maneira resumida, que precisamos lembrar na relação entre sujeito e objeto. Para reforçar essa afirmação, remetemo-nos a Lima (2019), para quem "se alinha uma premissa, sem a qual toda e qualquer acareação sobre o sujeito presumivelmente se invalidaria, a saber: a de que sujeito e objeto são entidades indissociáveis". Para ele, em outras palavras, "não há sujeito sem objeto e vice-versa", destacando que, na relação entre sujeito e objeto, pensar e agir permanecem no plano ontológico (LIMA, 2019 p. 15). Sujeito e objeto formam, portanto, um dos pares dialéticos básicos para a Geografia, mesmo que, historicamente, assim não tenham sido levados em consideração.

\section{OS SUJEITOS INSCRITOS NA SOCIOLOGIA E NA GEOGRAFIA}

Para elencarmos o papel do sujeito na produção do conhecimento geográfico, torna-se necessário discorrer, mesmo que brevemente, sobre algumas concepções teóricas e epistemológicas da noção de sujeito. Todavia, mesmo que as noções aqui apresentadas possuam um caráter epistemológico, entende-se que qualquer concepção de sujeito traz implícita ou explicitamente uma ontologia que a sustenta. Em outras palavras, o debate teórico dos sujeitos nas ciências humanas tem em seu cerne a discussão do ser em geral (homem e coisas), que serve de horizonte para fundamentação e desenvolvimento de uma concepção do que seja o homem.

O conceito de sujeito, assim como outras terminologias, como individuo, agente, ator, autor permeiam a teoria sociológica. Em relação a esta ciência, seu objeto constitui compreender as regularidades sociais que incidem sobre o comportamento humano. A sociologia clássica parte do pressuposto que a realidade social se transforma em virtude de processos objetivos que se impõem aos indivíduos como constrangimentos exteriores, atribuindo à estrutura social um peso preponderante na transformação da realidade social e na ação dos indivíduos. Neste contexto, Dubet (1994) argumenta que os sujeitos não estão presentes na sociologia tradicional, há a emergência dos atores, mas não como sujeitos, apenas como suportes de mecanismos sociais que estão além deles e que eles desconhecem. Por esta razão, o autor defende a sociologia da experiência, que enfatiza a capacidade e o papel dos sujeitos na construção da experiência.

A designação dos indivíduos como sujeitos na sociologia francesa é considerada um paradigma. $O$ uso desta terminologia nas ciências sociais deve-se aos estudos de Touraine (2006). A perspectiva dos sujeitos focalizada por este autor se enquadra, segundo Dubar (2004), no paradigma da sociologia clínica $^{3}$. Nesse paradigma, são as experiências dos sujeitos singulares que fornecem os dados a partir dos quais o cientista social intervém e constrói a sua interpretação, o sujeito aparece como um sujeito reflexivo que se engaja em um empreendimento de "retorno a si mesmo" e de explicação dos "acontecimentos biográficos". Para Dubar (2004), Touraine (2006) foge dos modelos precedentes como o de "agente ativo" e "agente estratégico" para uma espécie de sujeito existencial, ou seja, de um sujeito no mundo que se sente responsável por si mesmo e pela sociedade, cuja subjetivação se constrói pela consciência de si e da condução responsável da própria vida.

Dubar (2004) contribui para diferenciar agente, ator, sujeito, autor (que ele descreve como do mesmo para o mesmo). O ator é "autônomo, capaz de cálculo e de manipulação e que não apenas se adapta, mas inventa, em função das circunstâncias e dos movimentos dos seus parceiros" (p. 38). Os

${ }^{3}$ A sociologia Clínica nasceu devido a necessidade de elevar a compreensão a relação entre subjetividade e sociedade. Emerge no final do século XX de origem franco-lusófona (França, Bélgica e Canadá). Gedrin e Andreotti, 2017, p.145, citam Gaulejac e Hanique, (2007), para quem "a sociologia clínica coloca em tensão duas epistemologias que podem ser tanto complementares, como contraditórias: de um lado, a postura sociológica "de distanciam ento e de exterioridade" (lbid), e de outro, a postura clínica "de implicação e de interioridade.

Caminhos de Geografia $\quad$ Uberlândia-MG $\quad$ v. 22, n.82 $\quad$ ago./2021 $\quad$ p.173-190 Página 175


agentes, por outro lado, são sujeitos sociais que carregam o princípio da não-consciência (p. 58). Isto posto, a denominação de "agente" não se aplica como sinônimo ou qualificação do sujeito, como Dubar (2004) concebe e como queremos utilizar.

O indivíduo pode ser definido como a mêmeté 4 de "um sujeito regular relatando-se através das ideias e dos acontecimentos de sua biografia, concebida como produção da narrativa de si mesmo" (Dubar, 2004, p. 63). Para Dubar, (2004, p, 65). "definir o indivíduo como autor não é, portanto, atribuir-lhe uma autonomia todo-poderosa, mas fazer dele o produtor-enunciador de um discurso que, através das coerções do relato, induz e permite uma articulação entre determinações sociais e construção pessoal, socialização e estratégias

Para situar o sujeito na modernidade, Dubar (2004, p. 67) afirma que "os indivíduos-sujeitos enfrentam-se com crises inerentes à modernidade" pois "é assim que se tornam sujeitos, no sentido existencial do termo: deslocados em relação às suas múltiplas inserções, angustiados em face das incertezas de seus papéis de atores, fatigados e deprimidos por terem de ser eles mesmos".

Touraine (2006) pontua que o homem não pode ser considerado somente como um agente preso nas determinações sociais, como um ator mais ou menos estratégico, ou um indivíduo apenas reagindo às interações permanentes, mas que ele é, também, capaz de intervir naquilo que o determina e de contribuir para a produção de uma sociedade da qual, aliás, ele é produto. O sujeito descrito por este autor é o indivíduo que se rebela contra as condições sociais que lhes são impostas, emerge enquanto contestação na construção do indivíduo como ator. Não é desconectado de seu contexto social, mas na realidade não se coloca mais como um indivíduo em condições de sujeição e predestinação, mas se constitui como um sujeito que se constrói na historicidade, que se torna contestatório no âmbito de uma realidade social. Para Touraine (2006), o sujeito evoca a ideia de luta social, semelhante à de consciência de classe, contudo enquanto esfera individual. Configura-se como parte íntima de cada ser que possui como movimento a resistência, o confronto, o debate. Segundo o autor, "só nos tornamos plenamente sujeitos quando aceitamos como nosso ideal reconhecer-nos - e fazer-nos reconhecer enquanto indivíduos - como seres individuados, que defendem e constroem sua singularidade, e dando, através de nossos atos de resistência, um sentido a nossa existência" (TOURAINE, 2006, p. 123).

Que não fique a impressão de que utilizamos, com base no materialismo histórico, o mesmo conteúdo semântico para indivíduo e sujeito, embora alguns autores que estamos utilizando possam deixar essa impressão em algum momento. De maneira bem simplificada, o indivíduo é a pessoa que vive, que pensa e que se forma geograficamente segundo sua posição social e posição espacial. 0 sujeito, por sua vez, além de conter os atributos do indivíduo, eleva-se à condição proativa de agir e se torna conceito mais amplo e mais completo porque carrega, em si e para si, sua capacidade formada, historicamente, de ser condicionado e condicionar suas próprias ações por meio de sua posição e localização espacial; é no plano da abstração e na relação metodológica com o objeto que o sujeito se faz. A diferenciação entre os dois significantes ressalta, certamente, a fo rça do significado de cada um deles.

O sujeito descrito até o momento é o ser autônomo e ativo, que se contrapõe ao indivíduo que age segundo lógicas exteriores a ele (DUBET, 1994; TOURAINE, 1992). O sujeito deve compor, com as contradições que essas lógicas, geram em outros contextos. Ele deve assumir tensões, problemas, conflitos que the são impostos e construir assim as suas próprias trajetórias. É aí que intervém particularmente a preocupação geográfica, não apenas na compreensão da inserção e da leitura do sujeito nas categorias geográficas, mas também a forma como as dimensões territoriais e os lugares elevam a consciência de si (SARTRE e BERDOULAY, 2005).

Em síntese, o sujeito aqui evocado é o sujeito corporificado (RIBEIRO, 2000) que, através da relação corpo-espaço manifesta todas as suas objetividades e subjetividades no lugar. O sujeito corporificado é o homem vivo concreto proposto por Zaoual (2010), "cujo comportamento enraíza-se em um território"; "um homem social que pensa e age em uma situação" (ZAOUAL, 2010, p. 24 e 27). Há, portanto, uma relação implícita entre o sujeito (seu corpo) e o espaço, mas não uma relação positiva entre corpo e espaço, no sentido do qual o sujeito não mais aquele que restringe o objeto a um reflexo de suas subjetividades "mas, de outro modo, se deve a uma imbricação ontológica entre o homem e a realidade objetiva (geográfica) através do corpo" (LIMA, 2015, p. 4). Neste sentido, para

${ }^{4}$ Original na língua francesa. Isso pode ser traduzido, livremente, por "mesmice".

Caminhos de Geografia $\quad$ Uberlândia-MG $\quad$ v. 22, n. $82 \quad$ ago./2021 $\quad$ p.173-190 Página 176


Monnet (1999, p.126) o espaço (objeto da ciência geográfica) se constitui de maneira relacional entre o sujeito, constituindo como "a matéria da relação do sujeito ao objeto, de si para o outro, de nós a eles, do interior ao exterior, da consciência ao mundo. Que o espaço seja concebido em uma perspectiva objetiva, subjetiva ou trajetiva ${ }^{5}$, ele aparece sempre como condição da relação".

É nesta perspectiva de relação e de contradições que iremos construir alguns pares dialéticos entre o sujeito e alguns conceitos geográficos, tais como espaço, lugar e território.

\section{SUJEITO E ESPAÇO}

O primeiro par dialético que vamos trabalhar é sujeito/espaço. Antes de deixarmos noss a concepção desses conceitos, é necessário ressaltar dois pontos que norteiam as ideias aqui desenvolvidas. Primeiro é que parte dos apontamentos aqui apresentados estão baseados em Lima, (2014 e 2015), que propõe a emergência do sujeito na geografia e em múltiplas escalas. Para este autor, a consideração do sujeito no fazer geográfico enriquece a compreensão dos fenômenos geográf icos e é, portanto, uma possibilidade metodológica. Segundo ponto, o debate sobre espaço e sujeito implica em trazer à tona questões relacionadas a subjetividade e objetividade, pois é a análise da vivência dos sujeitos em uma base material que fornece a objetivação do objeto da ciência geográfica.

Segundo Lima (2014), o espaço é a expressão mais significativa da realidade objetiva do sujeito que, em todo o seu curso de vida e com toda capacidade de intersubjetividade, não é apreendida em sua totalidade. O sujeito apreende apenas uma parcela desta realidade objetiva que é o espaço geográfico. Para além de uma realidade do vivido, o espaço como um constructo de uma área do conhecimento é uma representação objetiva (ainda que reduzida) das experiências dos sujeitos. Esta realidade objetiva, quando elevada à categoria de objeto científico, passa a não ser entendida como um dado da experiência dos indivíduos, mas como um conceito geral e particular da ciência geográfica. Esta característica, "é, sem dúvida, um dado unificador dos afetos subjetivos acerca do espaço, mas também é um aspecto limitador do seu potencial objetivo, aquilo que o espaço de fato (ontologicamente) é" (LIMA, 2014, p. 2).

Ainda de acordo com Lima (2014), o espaço, considerado como um meio de nossa representação do mundo, passa a ser lido não como uma realidade ef etiva ou uma categoria do conhecimento, mas sim como um meio de realização do cotidiano. Já o espaço que emerge da corporeidade dos sujeitos se coloca como o espaço da geograficidade, "situa-se nos domínios do conhecimento e da ontologia" (LIMA, 2014, p. 2). A realidade geográfica espaço, que vai além da nossa possibilidade objetiva de apreensão do mundo, põe-se como "a superfície de contato com o corpo, ele partilha com o nosso corpo um princípio de conaturalidade, confiando-lhe, portanto, seus conteúdos indiscerníveis passíveis de serem apreendidos por meio da experiência" (LIMA, 2014, p. 3).

A ciência geográfica, comparado as outras áreas do conhecimento, é a que revela com maior clareza a totalidade do mundo em todas as suas esferas objetivas não discernidas "pela inteligibilidade ou mesmo percebidas numa apuração mais pormenorizada, de modo que estas condições estariam disponibilizadas pelo espaço geográfico enquanto um todo objetivo" (LIMA, 2014, p. 3). A geografia coloca-se, entre as ciências, como aquela que mais fornece ferramentas para analisar e explorar a relação (pouca estudada) sujeito e "a realidade efetiva do espaço, já que o corpo, condição fundamental desta possibilidade, mantém com ele certas afinidades ontológicas" (LIMA, 2014, p. 3).

Neste mesmo contexto, Lima (2014) pontua que uma das particularidades da ciência geográfica é a ausência de leis científicas gerais, fato que se deve à multiplicidade de concepções que caracterizam seu objeto, e por esta incluir "a maior complexidade de fenômenos e, ao mesmo tempo, preocuparse, mais do que a maior parte dos outros, com estudos de casos individuais (HARTSHORNE, 1978, p. 180)". Esta especificidade da geografia amplia a possibilidade de "contemplação dos sujeitos implicados nos fenômenos estudados", já que "a deificação do objeto a uma lei geral e apodítica, como ocorre, por vezes, com o próprio espaço, corrobora para a elisão do sujeito" (LIMA, 2014, p. 3).

${ }^{5} \mathrm{O}$ termo trajetiva advém do conceito trajeção que, segundo Ladeira (2016) "foi proposto por Augustin Berque e é relativo ao caminho, ao trajeto, ao movimento entre o físico e o fenomenal, entre o objetivo e o subjetivo. Conforme o autor, os "trajetos" de ordem fenomenal e os de ordem física são indissociáveis, na medida em que a realidade humana é física e fenomenal, objetiva e subjetiva simultaneamente. Em outras palavras, a trajeção corresponde a incessante troca entre o físico e o fenomênico que é a qualidade da realidade humana em sua relação ecumenal." (LADEIRA, 2016, p.26)

Caminhos de Geografia

. 22, n. 82

ago./2021

p. $173-190$

Página 177 
Ou seja, a herança da geografia como uma área do conhecimento que estuda os lugares ratifica o aparecimento dos sujeitos, mesmo que de forma passiva.

Em suma, observa-se que a geografia é uma área do campo científico com uma pluralidade de objetos, "todos reunidos sob o imperativo do espaço, que por seu teor de permeabilidade e de universalidade admite o intercruzamento dos mais variados objetos". A multiplicidade de conceitos que o objeto da ciência geográfica recebe, isto é, o espaço geográfico, implica na emergência de sujeitos difusos, "já que este [espaço] está sempre enredado numa relação de objetividade com o objeto para o qual se inclina" (LIMA, 2014, p.5).

A discussão sobre a definição de seu objeto que permeia o campo da geografia não a caracteriza como uma ciência de múltiplas geografias, isto é, como uma ciência em que a definição é particular a cada geógrafo (LIMA, 2014). Assim como qualquer outro campo do conhecimento, "a cons trução do saber geográfico somente é possível em face de um horizonte objetivo comum produto/produtor de um campo de intersubjetividade" (LIMA, 2014, p. 5). Para Lima (2015), "esta determinação concorre para um arrefecimento da multiplicidade de representações objetivas e, por conseguinte, para o estabelecimento de um sujeito em especial (em detrimento de tantos outros), assim como para afirmação de seu caráter passivo" (LIMA, 2015, p. 5).

Contudo, este caráter passivo poderia ser refutado com a assertiva que se colocou como paradigma da geografia e que norteia os estudos desta ciência na modernidade, "o espaço é um produto social ao passo que condiciona a própria produção social” (Lima, 2014, p. 5). Esta concepção de espaço geográfico, tornou-se um lugar comum no métier geográfico, mesmo com todas polifonias e dissidências que configuram o objeto desta ciência. Assim como Lima (2014), não refutamos esta afirmação, pois caracteriza a geografia moderna, mas devemos ter em mente que o caráter universalista desta assertiva "demanda um tipo especial de sujeito segundo uma circunvizinhança muito específica de subjetividades, ao passo que alija um sem-número de horizontes objetivos geográficos em potencial” (LIMA, 2014 p. 5). Parafraseando Neil Smith (1988), Lima (2014, p. 5), ressalta que esta concepção do espaço que permeia a geografia no contemporâneo "não é somente grosseira e mecânica na sua elaboração, mas também impede mais discernimento com relação ao espaço geográfico (...) isto se deve ao fato de que a visão da relação entre o espaço e a sociedade permanece presa à concepção absoluta de espaço" (SMITH,1988, apud LIMA p. 122), logo, não compreendendo os aspectos múltiplos e heterogêneos concernentes à subjetividade humana e à própria qualidade sensível do espaço. Não negamos que o espaço é um produto social, mas consideramos que este também é um dado da realidade que implica no "acontecer social, não como um a priori que precede a objetivação de seus conteúdos, mas sim por meio das formas legadas da formação socioespacial, do arranjo e da configuração territorial precedente, do acúmulo histórico de conteúdos na paisagem etc." (LIMA, 2014, p. 7).

As transformações nos conteúdos do espaço geográfico, interpretadas como uma realidade objetiva, colocam-se como um dado a ser descoberto e vivido pelo homem através da "conaturalidade entre o corpo, sede irredutível de toda experiência sensível, e o espaço geográfico, domínio material de to da a realidade geográfica" (LIMA, 2014, p. 9). É nesse sentido que a corporeidade e a geograficidade se tonam um elemento metodológico importante para compreender os fenômenos geográficos e suas transformações pela ótica dos sujeitos, como se verá ao longo deste texto. A relação espaço-corpo "confirma a máxima geográfica, segundo a qual, o espaço é a um só tempo produto, meio e condição social". O espaço enquanto meio e condição e produto, se coloca para Carlos (2011) como uma realidade prática que forma no âmbito da história econômica e social dos lugares. A autora, ao refletir sobre o processo de produção e reprodução do espaço (em uma visão lefebvriana), afirma que a reprodução da realidade sócio-espacial também forja a subjetividade dos indivíduos, e essa subjetividade é essencial para constituição da consciência socioespacial. Nas palavras de Carlos (2011, p. 11), "o homem se objetiva construindo um mundo real e concreto, ao mesmo tempo em que se subjetiva no processo ganhando consciência sobre essa produção".

Essa formação da subjetividade ocorre por meio da experiência corpórea, é a experiência enquanto geograficidade em modo geográfico de ser e existir, "que o corpo transcende a si mesmo por extensão de suas qualidades proprioceptivas e diacríticas" (LIMA, 2015, p.5). O corpo por suas características diacríticas é sensível à "materialidade mundana, como não nos deixa iludir as adaptações técnicas dos mais variados gêneros de vida sobre a face terrestre". Em outras palavras, "diríamos que o espaço desabrocha sentidos tornando evidentes conteúdos que até então 
permaneciam ocultos e forçando a transformação dos gêneros de vida, isto é, dos modos de existência adaptados às condições materiais por ele impostas" (LIMA, 2014, p. 9).

Considerar o sujeito na produção geográfica está além de evocar as assertivas homem-meio ou analisar seu caráter criativo, passivo e ativo na relação com a materialidade, mas sim o sujeito "enredado nos fenômenos geográficos, enquanto uma condição prática de sua existência material e de sua consciência" (LIMA, 2014, p.9). Desvendar os conteúdos das transformações do espaço pela ótica do sujeito, por considerar este um ser enredado pela relação corpo-espaço, permite, em síntese, a dotação de conteúdos a processos espaciais que, na realidade, são formas-conteúdos. É claro que este desvelamento tem sua implicação dialética com objetividade, mas "dialética entre a forma provisória e o conteúdo objetivado se dá sobre um 'fundo', isto é, sobre uma miscelânea de conteúdos informes passíveis de serem objetivados, consistindo, supostamente, em um plano abstrato por não aludir à concretude da forma-conteúdo" (LIMA, 2014, p.11).

\section{SUJEITO E LUGAR}

O conceito de lugar, na história do pensamento geográfico, tem recebido diferentes concepções. Suas significações remetem tanto a abordagens que priorizam os aspectos locacionais, isto é, do sítio, quanto referenciais teóricos que, ao darem significado ao lugar, elencaram questões vinculadas às relações humanas, ao afeto, o sentimento de pertencimento e a identidade do indivíduo com o lugar. Vale ressaltar que este conceito ganhou destaque principalmente na década de $1970 \mathrm{com}$ a geografia humanística por meio dos postulados de Yi-Fu Tuan.

Priorizaremos, neste artigo, as noções que valorizam a subjetividade e o papel da identidade na significação do lugar. São estes dois aspectos que nos ajudam a construir o par dialético sujeito/lugar. Por fim, para além da construção deste par dialético, elencaremos a fala como um instrumento metodológico para apreendermos esta relação.

Uma das principais contribuições da geografia humanista para a construção do conceito e as formas de analisar o lugar é a valorização da subjetividade e da afetividade. São através dos elos estabelecidos pelo sujeito com o espaço vivido que o lugar nesta corrente é construído. Ele é, portanto, o espaço marcado pela experiência e pela percepção. Neste sentido, é a experiência dos sujeitos que dá existência aos lugares. Para Tuan (1980), a relação de af eto com o lugar é traduzida pelo termo topofilia. Esta terminologia descreve os laços estabelecidos entre o sujeito com o ambiente e, por esta razão, é subjetiva, mas revela o ser geográfico. A topofilia seria, assim, o sentido geográfico, a escala da experiência e da ação, o elo af etivo entre o sujeito e o lugar. Avançando no conceito de lugar e sua relação com os sujeitos, Berdoulay e Entrikin (2012) destacam que estes são uma unidade pois, para eles, "um sujeito se transforma, ele próprio, ao transformar o mundo no qual se insere. É o jogo do distanciamento do sujeito, ativo e autônomo, em relação ao seu ambiente que prende nossa atenção, a fim de apreendermos a construção do 'entre-dois' que constitui", na perspectiva deles, "o lugar" (p. 103). Afirmam, ainda, que o lugar "exprime um trabalho do sujeito sobre o mundo e sobre sua relação com o mundo; ele é, assim, tensão a dois títulos, mas também tensão entre sua própria singularidade, que ele constrói, é sua inscrição universal." Por isso, "é preciso (...) recolocar o sujeito na perspectiva das relações que a consciência de si mesmo mantém com o lugar" (p. 103). A relação entre sujeito e lugar contém uma identidade espacial (p. 104) que varia em termos de escala, do bairro à nação, da nação pequena à nação grande. Assim, fazendo uma abordagem considerando a modernidade, os autores afirmam que ela "pode exigir a escolha entre o universal e o singular, mas o mais importante é a tensão entre os dois" (p. 107). Por isso é que precisamos pensar na centralidade do sujeito (como objeto de estudos) no âmago da geografia do ponto de vista das contradições que os conceitos formam e carregam em suas relações.

O lugar também imprime e exprime formas identitárias de ser. Pela ação, os sujeitos dotam os lugares de identidade, mas o lugar também imprime formas identitárias nos indivíduos. Segundo Gomes (2013), cada lugar incide de maneira única sobre os indivíduos, e estes absorvem a essência do lugar de maneira única também. Os lugares, pela ação dos sujeitos, imprimem formas de agir, maneiras de falar e de existir no espaço através do corpo. A forma pela qual os lugares af etam os sujeitos fornecendo possibilidades de ser para suas identidades é entendida nesse artigo como corporeidade, como já ressaltado anteriormente. 
Considerar a identidade como importante elemento para se entender o sujeito é colocar em evidência a necessidade de se "pautar a relação das sociedades e dos indivíduos com o espaço" (Berdoulay e Entrikin, 2012, p. 93). Os autores afirmam que o sujeito "forja sua própria identidade, sua consciência de si mesmo, em interação com o contexto de suas ações" (BERDOULAY e ENTRIKIN, 2012, p. 94). É, portanto, na perspectiva da nova tendência nas ciências sociais - que, na Geografia, perpassou a tendência fenomenológica e humanista - que as mudanças provocadas pelo que se chamou de pósmodernidade ${ }^{6}$, colocaram em evidência o sujeito na perspectiva de sua interação com o espaço ou, em outras palavras, em sua existência espacial. Repetindo: o evento da modernidade é fundamental para se compreender as proposições desses autores. Por outro lado, é na perspectiva do materialismo histórico que vamos expor nossos argumentos, mesmo que busquemos, em outras tendências científicas, argumentos que permitam diálogo com eles.

Berdoulay e Entrikin (2012) lembram que, para Giddens, (1987), os lugares são atores sociais que contêm os indivíduos (p. 102), o que pode levar à ideia teórica de desaparecimento dos lugares. Como sujeito e lugar são ligados e se determinam mutuamente (pelo foco da geo grafia humanista, orientação dos autores, p. 102), esta afirmação nega aquela de Giddens (1987). Por outro lado, o conceito de lugar deve considerar relações entre a objetividade e a subjetividade, o sujeito e o ambiente (BERDOULAY e ENTRIKIN, 2012, p. 103). Aqui nos deparamos com duas posições diferentes sobre a relação entre sujeito e lugar que não é, devemos lembrar, aquela que procuraremos enfatizar no texto.

Para avançarmos nas relações sujeito, lugar e identidade teceremos algumas questões sobre os processos de socialização apoiados em Lahire (2015). A socialização dos indivíduos ocorre em momentos, com temporalidades e intensidades distintas. Distinguir os tempos de socialização tornase relevante devido à importância que cada etapa tem na constituição do ser. Abreviadamente, há a socialização primária, que ocorre no seio familiar, sendo preponderante na formação dos indivíduos, como há, também, as socializações secundárias, que ocorrem na escolas, universidades, no âmbito das instituições (sejam elas, públicas, privadas, religiosas etc.), assim como no universo do trabalho (LAHIRE, 2015).

A socialização no lar pode ser focada por meio de uma homogeneidade do universo familiar que é "muitas vezes pressuposta e bem raramente observada. No entanto, quer a heterogeneidade seja relativa ou que ela leve às contradições/conflitos familiares mais exacerbados, ela está sempre irredutivelmente presente no cerne da configuração familiar que não chega nunca a ser uma 'instituição total' de socialização" (LAHIRE, 2015, p. 1399). Mas há, também, o papel das instituições que of erecem "um espaço de possibilidades pré-constituídas; regulam as disposições", isto é, coagem, censuram, "ao mesmo tempo em que lhes abre caminhos, colocando "as pulsões dos agentes a serviço de seus fins". Assim, "os diferentes agentes investem, em função de sua própria história e, portanto, de suas disposições, os significados propostos pela instituição dentre as quais eles privilegiam algumas" (BOURDIEU e MAITRE, 1994, p. v-xxii, apud LAHIRE ,2015, p. 1400).

Mas por que entraram, neste texto, as diferentes socializações do indivíduo? Porque sua formação é decorrente e decorre do lugar em que elas ocorrem. Para Lahire (2015), "os diferentes momentos de socialização na vida do indivíduo - primária (lar, mesmo com a "diversidade de ambientes, o que não pode ser considerado homogêneo", p. 1399), secundária (instituições, que deve levar em consideração os efeitos da primeira mas não é atualização dela, p. 1400) - não são equivalentes" (p. 1397) e pode haver socializações precoces ou que escapam à observação do cientista. Em resumo, a "socialização é processo contínuo na vida" (LAHIRE, 2015, p. 1401) e, na relação entre sujeito e lugar, ela é elemento sociológico importante para o entendimento da relação, com suas formas identitárias típicas.

Neste contexto, para além das leituras da relação sujeito/lugar através da identidade e afeto, é preciso considerar o lugar também com uma construção social como nas perspectivas de Santos (1994) e Carlos (2001). O lugar, na visão de Santos (1994), é caracterizado pelo movimento, por transformações e contradições. As mudanças no lugar estão relacionadas com as revoluções técnicas, e as contradições com as verticalidades e horizontalidades inerentes a um contexto globalizante. Para Arroyo (1996), a análise das contradições do lugar passa pela adoção de pares dialéticos como o método e seus elementos, isto é, o interno e o externo; o novo e o velho; o local e o

${ }^{6}$ e aqui fica a dúvida da periodização que se consagrou no final do século $X X$

p. $173-190$

Página 180 
global. A autora ainda salienta que o lugar pode ser lido como o espaço banal de Milton Santos, criador da solidariedade.

Para Carlos (2001), o lugar é "a base da reprodução da vida e pode ser analisado pela tríade habitante - identidade - lugar" (p.51). Por meio desta categoria analítica é possível elevar a compreensão sobre as transformações no contemporâneo vinculadas à globalização em diversas escalas, ou seja, pela relação local e global. Ainda para Carlos (2001, p.35), o lugar é o palco do vivido, possui usos, identidades, sentidos e abrange a vida social, "aparece como uma condição de realização da vida cotidiana".

Por fim, é preciso ressaltar que o lugar carrega a materialidade e o relato dos sujeitos fornecendo o meio de operacionalizar o conceito de espaço, mas para operacionalizar conceitos e processos através do discurso há de verificar os processos de subjetivação, em outras palavras, sua relação com o ambiente. Berdoulay e Entrikin (2012), afirmam que "o lugar, como sujeito, se institui e se exprime sobre o modo privilegiado da narrativa" e que o relato é a "entrada na geografia moderna, cujo alcance teórico e metodológico tem sido demasiadamente negligenciado" (p. 110). Neste ponto, há uma ideia muito ampla que procura levar o papel do lugar (como do sujeito, como aquele que tem a ação ativa) em relações que saltam diferentes escalas e perdem sua dimensão empírica. Mas o alcance teórico e metodológico pode ser analisado. Do ponto de vista da teoria, o conceito de lugar requer a relação de pertencimento e identidade por parte do sujeito. Do po nto de vista metodoló gico, não apenas análises qualitativas são fundamentais, mas a busca da dialética entre quantidade (os sujeitos existem, são contabilizados; consomem; têm vencimentos salariais etc) e qualidade (dimensões sociais que, se não derivam, pelo menos reiteram a quantidade, como posição de classe, formação socioespacial, momentos da educação etc). pode ser base para sua elaboração.

Para Dubar (2004), na sociologia clássica, a subjetividade dos sujeitos sociais é obstáculo ao conhecimento (p. 59) e, se não existe ator sem sistema, também não existe sistema sem atores sociais que o definam como um conjunto de relações de poder entre atores (p. 60). Para captar a subjetividade como ação individual ou coletiva, na ação metodológica da busca da info rmação, as entrevistas são técnicas importantes para esse fim7. A expressão do vivido é a linguagem (p. 62). E a linguagem entra, neste ponto, como elemento importante na transmissão da expressão do vivido. É sobre ela que vamos trabalhar um pouco.

Bakhtin (2002), a respeito da formação da consciência a partir da linguagem, defende a ideia de que todo signo é reflexo das estruturas sociais. Para esse autor, "a fala está indissoluvelmente ligada às condições da comunicação, que por sua vez, estão sempre ligadas às estruturas sociais" e "a palavra é o fenômeno ideológico por excelência". Por isso, "a realidade de toda palavra é absorvida por sua função de signo. A palavra não comporta nada que não esteja ligado a essa função, nada que não tenha sido gerado por ela. A palavra é o modo mais puro e sensível de relação social". (BAKHTIN, 2002, 36). Há pluralidade no uso da linguagem e diversidade dos pontos de vista que ela pode trazer (Dubar, 2004, p. 65).

A linguagem (que pode ser meio, também, quando se analisa a fala como expressão da subjetividade) auxilia no "desvendamento dos mecanismos do discurso - entendido enquanto linguagem, fruto de uma construção coletiva e histórica - e sua contribuição na constituição das representações regionais e como isso corrobora no forjar de sua identidade". Assim, o "discurso (a linguagem) é também um recurso na produção de significados e na construção de 'fronteiras' ou identidades regionais" (DUNDES, 2007, p 23). Há "estreita ligação que se tem entre, num âmbito mais amplo, da linguagem e das representações espaciais, e num âmbito circunscrito entre discurso, ideologia e representações espaciais" (DUNDES, 2007, p. 27$)^{8}$.

A importância do relato está no "poder que ele confere ao sujeito de interpretar seu mundo, de lhe dar sentido, qualquer que seja heterogeneidade dos fenômenos envolvidos". É através da narrativa que os sujeitos organizam e explicitam as especificidades espaço-temporal da experiência com o lugar, também, é por meio do relato que o sujeito "organiza seus laços com o ambiente e com a coletividade a ponto de, para certos filósofos, a trama narrativa aparecer como estruturante da vida do sujeito moderno" (DUNDES, 2007, p. 25). Essa trama entre sujeito e lugar possibilita o sujeito estruturar tanto o dizer e suas relações com o lugar, quanto o fazer, isto, a possibilidade de se tornar ator. Assim, o sujeito não é apenas enunciador da narração, mas, também, meio de instanciação entre o

\footnotetext{
${ }^{7}$ Sobre as técnicas de construir a informação a partir de uma abordagem empírica, voltaremos quando formos tratar do conceito de horizonte geográfico.

${ }^{8}$ Mais à frente vamos tratar das representações espaciais e dos espaços de representação pela ótica de Lefebvre (1986). 
lugar. É nesta trama desvelada no cotidiano do sujeito que sua relação com o lugar se coloca como um ferramental metodológico. Em síntese, o recurso ao conceito de lugar permite confrontar a exigência contemporânea de introduzir o sujeito na análise científica em geral e geográfica em particular, já que sujeito e o lugar se constituem mutuamente.

\section{SUJEITO E TERRITÓRIO}

Berdoulay e Entrikin (2012 p.96) afirmam que as questões inerentes às "relações de poder, às estruturações sociais e às relações sociais" têm mobilizado os estudiosos no âmbito da conceitualização do termo território. A conceituação de território trazida por eles reside, portanto, nos principais alicerces que, tradicionalmente, têm pautado os estudos do território: para esses autores, as relações de poder e as relações sociais que, neste ponto, podemos ampliar para as relações de classe e as possibilidades que têm as pessoas de se moverem no espaço, formam o conteúdo do território. Neste caso, estamos trabalhando o espaço em sentido mais geográfico do que o de lugar, para o qual o pertencimento é básico.

$\mathrm{Na}$ relação sujeito e território, torna-se interessante atentarmos para a construção do Estado. Neste contexto, Bourdieu (2013) afirma que "a construção do Estado é acompanhada pela construção de uma espécie de um transcendental histórico comum, imanente a todos os seus sujeitos". Através de relações de poder e enquadramentos o Estado impõe práticas "e inculca formas e categorias de percepção e de pensamento comuns, quadros sociais da percepção, da compreensão ou da memória, estruturas mentais, formas estatais de classificação". Em outras palavras, através das ações do Estado elencadas anteriormente, "este cria as condições de uma espécie de orquestração imediata de habitus que é, ela própria, o fundamento de uma espécie de consenso sobre esse conjunto de evidências compartilhadas, constitutivas do senso comum" (BOURDIEU, 2013, p.113).

Por outro lado, se o vivido é importante para a fenomenologia, aqui vamos procurar trazer o conceito de percebido e de vivido de Lefebvre, com a intenção de confrontar o mesmo significante com significados diferentes. A racionalidade do sujeito é algo que pauta entendimento de sua relação com o território. Aquilo que lhe é peculiar e intrínseco, no entanto, pode ser considerado não na perspectiva do espaço relacional proposto por $\mathrm{Harvey}^{9}$, (1984) mas na perspectiva da própria ação do sujeito em seu espaço social constituído por sua posição no território, sua posição social (condição cognitiva, etária, de classe, enfim, em sua complexidade como ator - na perspectiva daquele que tem a ação como resultado de suas decisões), ideia presente em Touraine (1992).

Berdoulay e Entrikin (2012) citam Touraine10 (1992, p. 313) para quem "o sujeito se define pela reflexividade à vontade, pela transformação refletida de si mesmo e de seu ambiente" (p. 99-100). Essa definição sociológica do sujeito pode levar a uma interpretação geográfica: o sujeito se define por sua reflexividade à vontade mas, também, por sua localização territorial, sua capacidade de se mover no território e sua posição social. Observemos que não está aqui presente a proposta de disciplinarizar o conceito de sujeito mas de trazer, para sua abordagem, um pouco da linguagem geográfica que, quer queiramos ou não, tem enraizamento no conhecimento e, mais, no pensamento que se constituiu a partir da formação de uma totalidade resultante de incontáveis estudos científ icos realizados ao longo da história da ciência.

Berdoulay e Entrikin (2012) afirmam que "os indivíduos e os grupos sempre teceram os laços entre identidade e espaço, como refletidos nas paisagens" em termos tradicionais mas, quando se considera a modernidade, a característica dos lugares é sua mutabilidade, "característica do sujeito moderno e de seu sentido de identidade" (p. 101). Não cabe, aqui, salientar a noção de essência (como elemento metodológico fundamental na fenomenologia), mas acentuar a concretude do território e da identidade dos sujeitos no sentido do materialismo histórico.

Pode ter havido uma ruptura, em algum momento dos estudos geográficos, na relação entre o sujeito e o lugar sem uma identificação específica, mas que pode ter tido grande contribuição da Escola de Chicago, de caráter eminentemente neopositivista, pois Berdoulay e Entrikin (2012) lembram que, para Vidal de La Blache, a "região, a localidade e o gênero de vida" seriam "os conceitos que

${ }^{9}$ HARVEY, David. A justiça social e a cidade. São Paulo: Hucitec, 1984.

10 Touraine A. (1992). Critique de la modernité. Paris Fayard. O livro de Touraine não foi estudado para este texto. A citação foi retirada de BERDOULAY, Vincent; ENTRIKIN, J. Nicholas. Lugar e sujeito: Perspectivas teóricas. In: MARANDOLA, E.; HOLZER, W.; OLIVEIRA, L. Qual o espaço do lugar? Geografia, Epistemologia, Fenomenologia. São Paulo: Perspectiva, 2012. Mesmo assim, a referência de Touraine está na bibliografia do texto para que o leitor possa fazer, também, sua leitura crítica do que afirmamos.

Caminhos de Geografia $\quad$ Uberlândia-MG $\quad$ v. 22, n.82 $\quad$ ago./2021 $\quad$ p.173-190 Página 182


permitem apreender as mediações que se tecem entre o homem e a natureza" (p. 103). Ora, a noção de gênero de vida provoca uma volta necessária ao passado para se tentar sopesar a importância de sua elaboração, mas não é o caso de detalhar, aqui, es se conceito lablachiano ${ }^{11}$.

No âmbito da ciência geográfica, a construção da identidade, tanto do indivíduo quanto do coletivo, vai além das características relacionadas ao sexo ou a origem étnica, mas, também, relaciona-se ao espaço geográfico e cultural que os grupos habitam (FONT e RUFí, 2006). Os grupos, neste contexto de construção da identidade, são preponderantes na constituição do fator identitário e na formação dos territórios. Ao se inserirem em um grupo, cultura, ao socializarem com seus pares, ou seja, ao vivenciarem trocas e experiências de diversas ordens, tais como emocional, intelectual, motora, entre outras, o sujeito se constrói enquanto ser social e, consequentemente, forma sua identidade, pois é através das interações com o grupo e da identificação com os mesmos que os sujeitos se reconhecem e são reconhecidos na sociedade. (HAESBAERT, 2006).

O território, para além da dimensão de poder, coloca-se como a base material e simbólica, sobre o qual os grupos constituem sua identidade. O território, portanto, ao ser composto por símbolos e signos, caracteriza-se como a base material e identitária de cada grupo social. Para Haesbaert (2006), a emergência do espaço enquanto território ocorre através da apropriação dos sujeitos. Apropriação esta que se manifesta através da política, economia, das relações sociais, culturais e das representações espaciais que imprimem usos, formas e significações aos territórios. São as relações e as representações espaciais que constroem os laços de pertencimento entre os sujeitos e os territórios. De acordo com Cruz (2007), a identidade territorial dos sujeitos é constituída por dois elementos, sendo eles: o espaço de referência identitária e a consciência socioespacial de pertencimento. O autor ressalta que a consciência espacial de pertencimento em relação aos lugares e territórios, isto é, a identidade, os laços, o reconhecimento com o grupo e sentimento de pertencimento, faz com que o individuo se reconheça como sujeito em relação ao lugar/território.

\section{HORIZONTE GEOGRÁFICO}

Neste item, o diálogo se faz na releitura da noção de horizonte geográfico como ela foi apresentada em 1983, para mostrar a importância da elaboração do conceito a partir da sua dimensão empírica.

Foi afirmado que, segundo Sposito (1983) "na rede urbana, além da distância entre os centros influenciar na locomoção das pessoas, claro, em virtude não só de sua grandeza simples, mas também dos tipos de transporte e frequência, a distribuição da riqueza entre as pessoas vai ser proporcional à sua capacidade de locomoção espacial". Vemos que está implícita, neste caso, a noção de mobilidade tanto do ponto de vista físico - meio, tipo de transporte, estradas e ruas quanto do ponto de vista socioespacial - frequência, distribuição da riqueza. Assim, a "Iocomoção espacial é fundamental na formação do horizonte geográfico da pessoa, que vai ter influência muito grande na sua capacidade latente ou em sua decisão real de migração" (p. 47). A definição primeira do horizonte geográfico seria, então, o "espaço mental e conhecimento da realidade organizado a partir da movimentação e das informações obtidas pelas pessoas cuja finalidade consequente é a percepção dos lugares" (p. 47).

Mais recentemente, Doreen Massey (2017), afirmou que "muito da nossa 'geografia' está na mente" (...) "nós carregamos conosco imagens mentais do mundo". As imagens podem, "por vezes, estar em conflito ou até mesmo ser a causa de conflitos". Ainda, seguindo Massey (2017), as "imaginações têm ef eitos poderosos sobre as nossas atitudes para com o mundo e sobre o nosso comportamento" ( $p$. 37). Por outro lado, não podemos recusar o fato de que existem "muitas históricas acontecendo ao mesmo tempo, que outros lugares têm suas próprias trajetórias particulares" (p. 38). Para ela, "se o tempo é a dimensão da sequência e da mudança, o espaço é a dimensão da coexistência e da multiplicidade" (p. 39). Assim, para a autora, uma "'mente geográfica' implica em uma atitude de uma mirada-de-fora-para-dentro que, ao reconhecer a diferença, também indaga necessariamente sobre os termos da negociação" (p. 39). Aqui ela trabalha a política do cotidiano, da convivência nos lugares pela ótica da negociação para a própria existência.

Trouxemos Massey (2017) para um diálogo porque ela faz suas afirmações que, se por um lado reforçam o que temos destacado no conceito de horizonte geográfico, por outro traz uma afirmação que pode ser entendida como inversão do que propomos. Quando ela afirma que a mente geográf ica implica em uma atitude de uma mirada-de-fora-para-dentro, está na mão inversa porque, para o

${ }^{11}$ Para uma leitura seminal do conceito de gênero de vida, v. HAESBAERT, R., PEREIRA, S. N., RIBEIRO, G. Vidal, Vidais. Rio de Janeiro:Bertrand Brasil, 2012, p. 131-184.

Caminhos de Geografia $\quad$ Uberlândia-MG $\quad$ v. 22, n.82 $\quad$ ago./2021 $\quad$ p.173-190 Página 183


conceito de horizonte geográfico, a mirada é de dentro para fora porque ela parte do sujeito, é dele para o mundo, é de mim para o mundo e não do mundo para mim. Esta é uma diferença importante: como o que propusemos é o resultado do que é vivido pelo sujeito, tem determinações externas condicionadas pelo modo capitalista de produção, é certo, mas é uma dimensão que se manifesta empiricamente no indivíduo (ora focado como sujeito na geografia). A mente geográfica, portanto, para nós, não "carrega" as imagens, mas forma as imagens que catalisam o cotidiano do sujeito.

Vamos a mais alguns detalhes. O horizonte geográfico foi concebido como elemento teórico para se compreender a migração mas, mais que isso, a permanência das pessoas em cidades pequenas, a partir das "viagens feitas pelas pessoas para fora da cidade individualmente, sobre a conceituação e a prática do lazer e sobre preferências individuais de lugares aspirados para residência que não aquela do momento da pesquisa, com suas respectivas imagens evocadas" (SPOSITO, 1983, p. 84). Enfim, as viagens foram tomadas como referência para a conformação inicial e a consequente análise do horizonte geográfico. Elas, em sua quantificação e qualificação, equivalem ao "passado no espaço de vida da população" (p. 86). Considerando o tempo como referência (mesmo que lembrando a herança heraclitiana), o "presente e o futuro podem ser analisados pela tendência voluntária à mudança, quesito que a maioria das pessoas respondeu no questionário" (p. 86). Desta forma, a mobilidade das pessoas balizada pelos deslocamentos no território formam um espaço mental que, uma vez apropriado pelo sujeito (que expõe sua acepção de espaço por meio da linguagem), torna-se a amplidão subjetiva que facilita e permite que ele tenha, além da própria vontade, a objetividade para tomar a decisão de se mover nas fronteiras por ele mesmo estabelecidas no plano abstrato. No entanto, o abstrato torna-se concreto porque o indivíduo não está isolado: ele faz parte de uma formação socioeconômica, teve sua socialização enquanto componente de vivência e faz parte de um grupo social com todas as suas singularidades (local de moradia, renda, posse de elementos físicos etc).

Já fora alertado que não se procurou estabelecer a elaboração da imagem que as pessoas manifestavam nem estudar características inerentes às imagens, como estrutura, identidade e imageabilidade (LYNCH, 1980), mas a partir da associação de estímulos citados pelos entrevistados a uma resposta - imagens da cidade estudada (SPOSITO, 1983).

Para demonstrar como o horizonte geográfico emergiu de uma abordagem empírica, as respostas foram agrupadas por meio de termos geográficos: clima (no sentido físico); lazer (respostas como: tranquilidade, sítio, fazenda, conforto, baile, praia, futebol, flores); família (respostas como: família, povo, infância); emprego (respostas como: fábrica, roça, chaminé); urbanização (respostas como: trânsito, edifícios, topografia, insegurança, casas ricas, poluição, praça, capital regional, limpeza); e serviços (respostas como: lojas, transportes, bancos, escolas, atendimento médico) (SPOSITO, 1983).

Para não generalizar o que foi utilizado, nem sempre as respostas podem ser consideradas como representativas do conceito de "imagem", mas foram consideradas válidas pelo próprio alcance de observação do entrevistado dado, muitas vezes, pelo desconhecimento do teor da pesquisa - por parte do entrevistado. Assim, "surgiram as imagens de dados físicos como sítio, fazenda, praia, flores, fábricas, edifícios, praça, como também apareceram noções, como poluição, família, infância, capital regional, atendimento médico ou estados de espírito, como tranquilidade ou insegurança". Os seis grupos organizados podem, por outro lado, ser reunidos em dois subgrupos diferentes: "o primeiro, reunindo clima, lazer e família e, o segundo, reunindo emprego, urbanização e serviços". A proposta desse reagrupamento "foi feito porque o segundo grupo tem imagens diretamente relacionadas à rede urbana e suas funções, enquanto que o primeiro grupo se dispersa mais para o lado pessoal e da família" do indivíduo, "com sua histó ria e suas aspirações em consideração". Assim, mesmo que essa forma de construção do horizonte geográfico a partir de dados obtidos por meio de questionários (portanto, com perguntas e respostas previamente elaboradas), "esses dados limitam o horizonte geográfico das pessoas, em primeiro plano, aos limites da cidade, e em segundo plano, às cidades mais próximas da região" (Sposito, 1983, p 84). Essa conclusão permite apreender a formação de um espaço de representação que é apreendido, pelo sujeito, em escalas local e regional; portanto, demonstrando a possibilidade da articulação de escalas na representação do espaço.

Aqui o diálogo com Lefebvre (1986) pode auxiliar a conformar o conceito de horizonte geográfico. Para isso, partimos do que ele chamou de triplicidade: percebido-concebido-vivido. Ele considera essas noções quando se reporta ao corpo: "uma vez que a relação com o espaço de um 'sujeito', membro de um grupo ou de uma sociedade, implica sua relação com seu próprio corpo e reciprocamente" (p. 36). O percebido refere-se à "base prática da percepção do mundo exterior, no sentido dos psicólogos"; o "vivido corporal alcança um alto grau de complexidade e de estranheza, 
pois a 'cultura' aí intervém sob a ilusão de imediatidade, nos simbolismos e na longa tradução judaico-cristã” (p. 36). O vivido difere do pensado e do percebido.

Lef ebvre (1986) trata do percebido-concebido-vivido quando expõe suas ideias sobre os espaços de representação e as representações do espaço. Para ele, "os espaços de representações, vividos mais que concebidos, jamais se sujeitam à coerência, não mais que à coesão" (p 52); o "espaço de representação se vive, se fala" (p. 52). Por outro lado, "pode-se antecipar [esperar] que as representações do espaço tenham um alcance prático (...) e teriam, "assim, um alcance considerável e uma influência específica na produção do espaço” (p. 52). Continuando o diálogo com Lefebvre: para ele "as representações do espaço, ou seja, o espaço concebido, aquele dos cientistas, dos planificadores, dos urbanistas, dos tecnocratas 'retalhadores' e 'agenciadores' ( $p$. 48) identifica o vivido e o percebido ao concebido". Já os espaços de representação, ou seja, o espaço vivido através das imagens e símbolos que o acompanham", trata-se do "espaço dominado" (p. 49) que a imaginação tenta modificar e apropriar" (p. 35).

Schimid (2012, p. 103) resume e esclarece que, para Lefebvre (1986),

“Espaço percebido:o espaço tem um aspecto perceptível que pode ser apre endido por meio dos sentidos. Essa percepção constitui um componente integral de toda prática social. Ela compreende tudo que se apresenta aos sentidos; não som ente a visão, mas a audição, o olfato, o tato e o paladar. Esse aspecto sensualmente perceptivo do espaço relaciona-se diretamente com a materialidade dos 'elemento s' que constituem o 'espaço'.

Espaço concebido: o espaço não pode ser percebido enquanto tal sem ter sido concebido previamente em pensamento. A junção de elementos para formar um "todo" que é então considerado ou designado como espaço presume um ato de pensamento que é ligado à produção do conhecimento ${ }^{12}$.

Espaço vivido: a terceira dimensão da produção do espaço é a experiência vivida do espaço. Essa dimensão significa o mundo assim como ele é experimentado pelos seres humanos na prática de sua vida cotidiana. Neste ponto, Lefebvre é inequívoco:o vivido, a experiência prática, não se deixa exaurir pela análise teórica. Sempre permanece um excedente, um remanescente, o indizível, o que não é passível de análise apesar de ser o mais valioso resíduo, que só pode ser expresso por meio de meios artísticos". (p. 103).

Essas propostas de Lefebvre (1986) são matéria prima para continuarmos o diálogo. Vamos lá. O que foi considerado horizonte geográfico é atinente à formação de um "espaço mental" derivado do "conhecimento da realidade" que se organiza "a partir da movimentação" (mobilidade das pessoas por diferentes meios de locomoção, em diferentes tempos e diferentes intensidades) e das "informações obtidas pelas pessoas" (em forma de fatos, dados, imagens, pulsões) cuja "finalidade consequente é a percepção dos lugares" (Lefebvre, 1986). Para este autor, "espaço mental” está atrelada ao "espaço abstrato" da filosofia, matemática, física; é o espaço que está separado do espaço social. No entanto, vamos repetir o que ele escreveu: é derivado do conhecimento da realidade que se organiza a partir da movimentação e das informações obtidas pelas pessoas. Seria possível dar outro significado às palavras acima e trazê-las para sustentar a formação do horizonte geográfico por meio da movimentação espacial das pessoas?

A dimensão que mais se adequa, neste caso, é o conceito de espaço vivido (porque é a mobilidade das pessoas - acrescida, sem relação hierárquica, da acessibilidade - do ponto de vista empírico, que permite a formação mental do espaço de movimentação possível (mas que não aparece do nada, pois é resultado da vivência das pessoas) no âmbito do cotidiano. Acrescentamos a ideia de que essas características do horizonte geográfico reportam ao "domínio" territorial em termos mentais e

12 Alves (2019) interpreta o seguinte: "Lefebvre chama de espaço concebido ou de representação do espaço a dimensão espacial ligada às relações de produção, ao conhecimento, ao planejamento, à ordem instituída" ( $p$. 556). Ela parte de excerto do livro de Lefebvre (A produção do espaço) que traduz em seu artigo: "as representações do espaço, ou seja, o espaço concebido, o espaço dos cientistas, planejadores, urbanistas, tecnocratas fragmentadores, engenheiros sociais e até um certo tipo de artistas próximos à cientificidade, to dos os quais identificam o vivido e o percebido com o concebido (o que perpetua as velhas especulações sobre números: número áureo, módulos, cânones etc.), é o espaço dominante em qualquer sociedade (ou modo de produção). As concepções do espaço tenderiam (com algumas exceções às quais seria parecido voltar) a um sistema de signos verbais" (p. 556). As duas interpretações podem se completar, mas mostram que, a partir da obra de Lefebvre, podemos fazer leituras diferentes sobre seus conceitos de acordo com nossa formação, posicionamento em relação à ciência, por exemplo.

$\begin{array}{lllll}\text { Caminhos de Geografia } \quad \text { Uberlândia-MG } & \text { v. 22, n. } 82 & \text { ago./2021 } & \text { p.173-190 Página } 185\end{array}$


sentimentais das pessoas que ultrapassa as fronteiras do lugar, segundo o qual a noção de pertencimento se torna mais precisa.

Segundo Schmid (2012), "o núcleo da teoria da produção do espaço identifica três momentos da produção: primeiro, a produção material; segundo, a produção de conhecimento; e, terceiro, a produção de significados (p. 105).

Não se trata de fazer uma comparação com as denominações de Lefebvre para buscar similaridades que as aproximem do horizonte geográfico. Mas se trata de ver o que pode ser realçado num diálogo em termos teóricos. O que mais se aproxima, portanto, do horizonte geográfico seria o espaço vivido exposto por aquele autor, sem negligenciar a inseparável triplicidade (vivido e percebido + concebido). Trazemos o concebido para dizer que ele pode ser resultado da movimentação das pessoas e da combinação de movimentação com informações (principalmente na atualidade, quando a velocidade das tecnologias da informação e da comunicação expõem, a todo momento e aproximadamente vinte e quatro horas por dia, novidades ou repetições que impactam a percepção das pessoas). O concebido, neste caso, ao nosso ver, torna-se mais complexo que o percebido ("base prática da percepção do mundo exterior" (LEFEBVRE, 1986, p. 36) e do vivido - influenciado pelos simbolismos e, na "sociedade do consumo" - como afirmou Baudrillard (2011); o espírito se plenifica com o ter, muito mais do que com o ser, mesmo que, neste caso, o ser seja uma singularidade que pode ser enfocada como uma totalidade individual.

Para terminar o diálogo (que não seja apenas neste parágrafo), queremos lembrar que, mesmo que as palavras (a linguagem é compósita e complexa ${ }^{13}$ ) possam ser diferentes, elas podem remeter a conceitos que se aproximam, mas que permanecem com suas características de origem e de autoria. Assim, reafirmamos o conceito de horizonte geográfico como possibilidade de situar o indivíduo (como sujeito) em relação ao espaço e, mais especificamente, ao território e ao lugar.

\section{GEOGRAFICIDADE}

Outro conceito que pode auxiliar na compreensão do sujeito e sua relação com o espaço pode ser o de geograficidade. Neste caso, vamos nos ater a uma obra que resume, em todo o texto, esse conceito: "para entender o que se quer dizer com geograficidade (...) é preponderante que se delimite a aplicação desta derivação de sufixo para, posteriormente, inter-relacionar seu significado morfológico com o caráter epistemológico" (CIRQUEIRA e SPOSITO, 2019, p. 36).

A geograficidade foi buscada nas obras de Elisée Reclus e, por esta razão, "ela se expressa através do enlace entre o homem/mulher e a Terra, suas interações, condicionamentos e transformações, abordados em sua magnitude como elementos centrais da forma de refletir o saber geográfico". Assim, "ela é vista como o modo de existência do humano em seu meio". Nas interações entre o ser humano e seu meio, há "profunda integração entre o ser humano e o planeta em que ele vive, com toda sua diversidade de acidentes geográficos e de outros seres vivos" (CIRQUEIRA e SPOSITO, 2019, p. 38).

A geograficidade é caracterizada por ser pluridiscursiva, feita de vida, de suor, alegria e prazer, de sangue, de luta e de liberdade, para ser útil à mesma vida de suor, sangue, luta, alegria, prazer e liberdade em que elas foram gestadas. Pode ser interpretada como as experiências geográficas vividas pelos sujeitos e elevadas à compreensão através do saber geográfico. Portanto, a geograficidade se distancia "da geografia de gabinete", que somente compõe "o edifício acadêmico ortodoxo e as práticas opressoras do capital e do Estado". É uma geografia, que era para ser desde o início, existencial e dissidente. (CIRQUEIRA e SPOSITO, 2019, p. 26).

As geografias pluridiscursivas abarcam o vivido, com suas dissidências e existências enquanto as práticas opressoras do Estado estariam no plano do concebido ${ }^{14}$. A geograficidade é "sustentada pela perspectiva do engajamento existencial, tendo os espaços e suas manifestações dialéticas de classes, e seu mergulho nesse oceano complexo do social e cultural o substrato para a formação de suas personalidades". (CIRQUEIRA e SPOSITO, 2019, p. 27)

Outro argumento que justifica esse conceito é aquele que enfatiza que "o pensamento de Reclus e Kropotkin foi gestado pela experiência espacial, marcada pelo confronto entre o entendimento da natureza e os embates das lutas de classe", que formam "suas geograficidades de dissidência, que

${ }^{13}$ V. SPOSITO, Eliseu S. Geografia e Filosofia. São Paulo: Editora UNESP, 2004, p.

${ }^{14}$ Agradecemos a Cláudio Smalley Pereira por ter sugerido essa ideia articuladora entre a geograficidade, 0 vivido e o percebido. 
veiculam o discurso das liberdades, da organização do espaço, do equilíbrio e da autogestão do território à práxis espacial". (CIRQUEIRA e SPOSITO, 2019, p. 29).

Além do mais, CIRQUEIRA e SPOSITO (2019) afirmam que "a geograficidade não corresponde somente à produção de saberes objetivos sobre o mundo, mas, sobretudo, de colocar em ação certo sentido de mundo e de sua dimensão enquanto fundamento da experiência existencial" (p. 58). Enfim, em resumo que pode perder a riqueza dos detalhes reclusianos, há uma relação direta entre "geograficidade, modo de ser e experiência" (p. 33).

Para mostrar ao leitor a complexidade que o conceito de geograficidade foi tomando ao longo do tempo (por causa de contribuições enriquecedoras como as de Dardel,1952 e Claval, 1974), podemos enumerar suas características: 1) do ponto de vista epistemológico, "como experiência de relação e de distinção das formas da superfície da Terra"; 2) do ponto de vista ontológico, "geograficidade do ser humano como modo de sua existência e de seu destino"; 3) do ponto de vista pragmático, ela "pode ser vista como modelo de ação, práticas e de conhecimentos geográficos" e "como sentido da marcha histórica" (CIRQUEIRA e SPOSITO, 2019, p. 59-61).

Um lembrete que trazemos é que (baseados em CIRQUEIRA e SPOSITO, 2019), "os geógrafos devem partir da posição de que a geograficidade deve ser a representação do que é próprio do ser geográfico, havendo assim uma equivalência historiográfica dos conceitos" ( $p$ 63) e "a geograficidade aparece, em si, para sustentar a ideia segundo a qual a geografia é mais que uma ciência, ela é uma dimensão fundamental e original da existência humana" (p. 63).

Em termos mais amplos (ou grosso modo),

\begin{abstract}
"é possível encontrar na geograficidade reclusiana tanto a dimensão ontológica - de que a geograficidade humana precede a ciência geográfica, por isso é vista com o a dimensão constitutiva da humanidade - como a dimensão epistemológica, em que se coloca no centro do debate a questão fundamental do que é geográfico, trazendo a responsabilidade e especificidade do olhar geográfico, valorizando, assim, cada vez mais o modo de ser do geográfico e os parâmetros técnicos desta abordagem corográfica da superfície; quanto, ainda, a abordagem historiográfica, em que se identifica a equivalência do conceito de historicidade com o de geograficidade, alinhando o sentido do ser histórico da consciência com o do ser geográfico da consciência social. Desse modo, pode-se considerar a valorização da geograficidade reclusiana como primordial para o desdobramento das reflexões acerca da geograficidade subsequentes, reconhecendo pontos de equivalência e fragm entos de composição desta geograficidade primeira, inacabada e não classificada como tal, nas posteriores geograficidades formais, elaboradas e discutidas" (CIRQUEIRA e SPOSITO, 2019, p. 64).
\end{abstract}

Enfatizando, "o sentido paradigmático da geograficidade [aqui com o adjetivo libertária] reside na abordagem realizada da relação mulher-homem-meio, sociedade-natureza e das diferenciações espaciais, por considerar os fatores de intencionalidade e de condicionalidade da ação humana na terra" (CIRQUEIRA e SPOSITO, 2019, p. 68). A natureza é parte fundamental da existência humana. Para o reforço dessa assertiva, podemos buscar, para enriquecer esse aspecto da geograficidade, a importância que Lefebvre dá a ela: não se trata apenas da natureza exterior, mas também da natureza interior ao indivíduo [aqui tratado como sujeito]. Seabra (1996) lembra, muito bem, que o homem, visto como generalidade, "força de trabalho", e "gradativamente, como força de trabalho", "por suas particularidades, pelos seus atributos" (...) sociais e históricos", enfim o "ser humano que vem da história, nunca se separará por completo da natureza, mesmo passando pela antinatureza, pela abstração" (p. 70). A natureza não elimina a experiência do mundo nem o sentido paradigmático da geograficidade, mas é elemento indissociável desta porque não pode ser entendida à parte, co mo algo estranho ou secundário; ao contrário, é essencial na sua conceituação. Ela faz parte da lógica teórica da geograficidade, existe em relação contraditória com o sujeito sem dele se alienar. Seabra (1996) afirma que a noção e o conceito de natureza se ampliam e, no cotidiano, "lugar de embate entre o concebido e o vivido, estão os enigmas pelos quais se discute a sociedade e o social para compreender o uso" (p. 72). A autora completa afirmando que, "no entanto, é no vivido, como o nível da prática imediatamente dada, que a natureza aparece e transparece, como corpo, como uso" ( $p$. 75).

O distanciamento no tempo entre os dois teóricos (Reclus - século XIX - e Lef ebvre - século XX) não é condição para associar suas proposições porque, ao nosso ver, eles tiveram, em seus momentos históricos determinantes, como base, o primeiro, o embate com o materialismo histórico de Marx e Engels e, o outro, a leitura crítica da obra de Marx e o papel de trazê-la para o nível do cotidiano, do corpo. Por isso, podemos concluir que a geograficidade é um conceito que pode incorporar, na 
atualidade, contribuições de diferentes origens desde que tenham, por trás, a dialética como método de produção e de interpretação do conhecimento.

Mais argumentos para explicitar a geograficidade: "como experiência do/no mundo", como explicou Dardel (1952), ela é "fundamento existencial". Mas "a gênese desta condição do vivido como experiência do/no mundo é oriunda de tempos imemoráveis do saber geográfico". Tanto para Elisée Reclus como para Dardel, essa sempre foi uma questão chave, ou seja, uma "preocupação latente no que tange à fragmentação e ao desequilíbrio desta relação íntima dos homens com o meio" (CIRQUEIRA e SPOSITO, 2019, p. 71).

Se, em tempos pretéritos, a geograficidade foi comparada (no sentido ontológico e inerente ao saber geográfico) à sociabilidade, ao gênero de vida e, mais recentemente, ao meio técnico, em plena época da quarta revolução industrial, ela tem que levar em consideração as tecnologias de informação e comunicação ou, ainda mais, a constituição da sociedade em rede, para ser apropriada para a "compreensão das tendências societárias de nosso tempo". Neste sentido, ela é "adequada para entender a existência espacial dos homens; ela é, dessa forma, colocada no centro das investigações geográficas, mas sempre avaliada genericamente, como um todo que delineia o saber espacial" (CIRQUEIRA e SPOSITO, 2019, p. 73). Em termos de avaliação do conceito, "quando se cogita discutir a geograficidade pelo prisma da experiência do/no mundo está sendo colocado um acento sobre a episteme existencialista no interior deste saber" ou "é uma experiência do mundo porque pertencem ao jogo de relações, interações e condicionalidades que o mundo conduz" (CIRQUEIRA e SPOSITO, 2019, p. 77), para buscarmos construir uma geograficidade dos fatos (p. 114).

Enfim, esse conceito (geograficidade) pode ser reavaliado como uma possibilidade teórica de compreender o sujeito em sua relação com o espaço (nele, com ele e por ele), valorizando sua dinâmica constituição de acordo com as condições do momento histórico e a complexidade das relações de produção.

\section{CONSIDERAÇÕES FINAIS: A ESPACIALIDADE DO SUJEITO EM DIFERENTES}

À guisa de conclusão, a espacialidade do sujeito em diferentes escalas pode pressupor os conceitos trabalhados neste texto em termos de sua dimensão individual ou coletiva, de sua possibilidade de empiricização a partir de sua sustentação teórica e na interdisciplinaridade evocada ao longo dos diálogos. Algumas teses podem auxiliar no arranjo de nossa argumentação:

- O sujeito, com a assunção do pertencimento e da identidade, é afirmação e negação do lugar. Neste caso, eles estão em relação dialética e em escala local.

- O sujeito, quando enfocado em relação ao território, deve ser focalizado por meio das relações de poder e, mais amplamente, relações sociais (classes), que condicionam sua mobilidade e acessibilidade (possibilidades de se mover no espaço). Aqui temos a articulação entre as escalas local, regional e nacional.

- O horizonte geográfico, que pode ser lido, também, como espaço vivido, é constituído pela mobilidade do sujeito no espaço, conforma seu território e lhe dá a dimensão do lugar; é a possibilidade de abstração de sua concretude no mundo, existência em classe social, que se move horizontal e verticalmente no mundo da mercadoria e do trabalho, da produção de riquezas e na alienação do resultado de suas atividades.

- A geograficidade é uma leitura teórica, como já afirmado anteriormente, do "enlace entre o homem/mulher e a Terra, suas interações, condicionamentos e transformações, abordados em sua magnitude como elementos centrais da forma de refletir o saber geográfico" (CIRQUEIRA e SPOSITO, 2019, p. 9). Ela é modo de existência, integração entre o ser humano e o planeta, a diversidade, as articulações, a superfície da Terra e os movimentos acima dela.

Não a soma, mas a atenção a esses conceitos pode, respeitando a relação entre sujeito e objeto (com a intermediação do método), auxiliar a situar o sujeito no mundo e desvendar sua densidade.

\section{AGRADECIMENTOS:}

Este texto está associado ao desenvolvimento da pesquisa financiada pela FAPESP (Fundação de Amparo à Pesquisa do Estado de São Paulo), na modalidade projeto temático (processo 2018/07701 8), intitulada "Fragmentação socioespacial e urbanização brasileira: escalas, vetores, ritmos, formas e

$\begin{array}{lllll}\text { Caminhos de Geografia } \quad \text { Uberlândia-MG } & \text { v. 22, n. } 82 & \text { ago./2021 } & \text { p.173-190 Página } 188\end{array}$


conteúdos". O texto também está associado a outra pesquisa financiada pela FAPESP (vinculada ao projeto citado acima, na modalidade Bolsas de pós-doutorado processo 2019/04392-7)

\section{REFERÊNCIAS}

ALVES, G. A. A produção do espaço a partir da tríade lefebvriana concebido/percebido/ vivido. Geousp, v. 23, n. 3, p. 551-563, dez. 2019. https://doi.org/10.11606/issn.21790892.geousp.2019.163307

ARROYO, M. A trama de um pensamento complexo: espaço banal, lugar e cotidiano. In: CARLOS, A. F. A. (org.). Ensaios de Geografia contemporânea: Milton Santos, obra revisitada. São Paulo: Hucitec, 1996, p. 55-62.

BAKHTIN, M. Marxismo e filosofia da linguagem. São Paulo, Hucitec, 2002.

BAUDRILLARD, J. A sociedade do consumo. Lisboa: Edições 70, 2011.

BERDOULAY, V.; ENTRIKIN, J. N. Lugar e sujeito: Perspectivas teóricas. In: MARANDOLA, E.; HOLZER, W.; OLIVEIRA, L. Qual o espaço do lugar? Geografia, Epistemologia, Fenomenologia. São Paulo: Perspectiva, 2012.

BOURDIEU, P. "Espírito de Estado: Gênese e Estrutura do Campo Burocrático" In: Razões

Práticas - Sobre a teoria da ação. Papirus Editora, Campinas SP, 11aㅡ edição, 2013.

BOURDIEU, P; MAITRE, J. Avant propos dialogué avec Pierre Bourdieu. In: MAITRE, Jacques. L'autobiographie d'un paranoïaque. Paris: Anthropos, 1994.

CARLOS, A. F. A. O lugar no/do mundo. São Paulo: FFLCH, 2001. p. 21-27.

CARLOS, A. F. A. A condição espacial. São Paulo: Contexto, 2011. 157 p.

CHAUI, M. Primeira Filosofia: lições introdutórias. São Paulo: Brasilense, 1986.

CIRQUEIRA, J. V., SPOSITO, E. S. Geograficidade. Modo de ser, experiência e prática social. Curitiba: Appris, 2019.

CLAVAL, P. Evolución de la Geografía Humana. Barcelona: Oikos-tau, 1974.

CRUZ, V. do C. Territorialidades, identidades e lutas sociais na Amazônia. In: ARAÚJO, F. G. B. de; HAESBERT, R. Identidades e territórios: questões e olhares contemporâneos. Rio de Janeiro: Access, 2007. Cap. 05, p.93 a 122.

DARDEL, E. L'homme et la terre. Nature de la réalité géographique. Paris: PUF, 1952.

DUBAR, C. Agente, ator, sujeito, autor: do semelhante ao mesmo. Primeiro Congresso da Associação de Sociologia da França, p. 56-69, 2004.

DUBET, F. Sociologia da experiência. Lisboa: Instituto Piaget. (Coleção epistemologia e sociedade), 1994.

DUNDES, A. C. Região do devir e região do atraso. Discurso e representações sobre a região de Presidente Prudente, SP. Presidente Prudente: UNESP, 2007 (Tese de Doutorado).

FONT, J. N., RUFÍ, J. V. Geopolítica, identidade e globalização. São Paulo: Annablume, 2006.

GAULEJAC, V., HANIQUE, F., ROCHE, P. La sociologie clinique, enjeux théoriques et méthodologiques. Toulouse, 2007.

GEBRIM, A.; ANDREOTTI, R. Sociologia Clínica e Psicossociologia: a noção de implicação do pesquisador. Teoria \& Sociedade (UFMG), v. 1, p. 142-157, 2017.

GIDDENS A. La constitution de la société. Paris, Presses Universitaires de France.1987.

GOMES, P. C. da C. O lugar do olhar: Elementos para uma geografia da visibilidade. Rio de Janeiro: Bertrand Brasil, 2013. p. 27-182.

HAESBAERT, R.; PEREIRA, S. N., RIBEIRO, G. Vidal, Vidais. Rio de Janeiro: Bertrand Brasil, 2012. HAESBAERT, R. O Mito da Desterritorialização: do fim dos territórios à multiterritorialidade. 2. ed. Rio de Janeiro: Bertrand Brasil, 2006. v. 1. 400p

HARTSHORNE, R. Propósitos e natureza da geografia. São Paulo: Editora Hucitec, 1978, 203p. HARVEY, D. A justiça social e a cidade. São Paulo: Hucitec, 1984. 
LADEIRA, M. Y. Paisagem: cultura-natureza em perspectiva. Uma abordagem trajetiva do conceito de paisagem. 2016. Tese (Doutorado em Geografia Física) - Faculdade de Filosofia, Letras e Ciências Humanas, Universidade de São Paulo, São Paulo, 2016. doi:10.11606/T.8.2017.tde06012017-110558. Acesso em: 2020-06-14. https://doi.org/10.11606/T.8.2017.tde-06012017-110558

LAHIRE, B. A fabricação social dos indivíduos: quadros, modalidades, tempos e efeitos de socialização. Educação e Pesquisa. São Paulo, 2015, v.41, p. 1393-1404. https://doi.org/10.1590/S1517-9702201508141651

LEFEBVRE, H. La production de l'espace. Paris: Anthropos, 1986, 3ème édition.

LIMA, E. L. de. O sujeito na encruzilhada do conhecimento geográfico. Revista Paisagens \& Geografia. Campina Grande: UFCG, 2019, p. 10-24.

LIMA, E. L. de. A corporeidade como um recurso metodológico da geograficidade. Juiz de Fora: Núcleo de Geografia, Espaço e Ação (NUGEA/UFJF), 2015.

LIMA, E. L. de. O sujeito entre múltiplas geografias e a geografia geral. Juiz de Fora: Núcleo de Geografia, Espaço e Ação (NUGEA/UFJF), 2014.

LYNCH, K. A imagem da cidade. São Paulo: Martins Fontes, 1980.

MASSEY, D. A mente geográfica. GEOgraphia. Niterói: UFF, v. 19, n. 40, 2017, p. 36-40 (Dossiê Doreen Massey). https://doi.org/10.22409/geographia.v19i40.1193

MONNET, J. Interpréter et aménager: eléments d'une géographie de la relation au monde. Dossier de canidacture à l'habilitation à diriger les recherches. Paris, 1999.

RIBEIRO, A. C. T. Sujeito corporificado e bioética: caminhos da democracia. Revista Brasileira de Educação Médica, Rio de Janeiro. V.24, n.1, jan/abril, p. 82-86, 2000.

SANTOS, M. Metamorfoses do espaço habitado. 3o ed. São Paulo: Hucitec, 1994.

SARTRE, X. A.; BERDOULAY, V. Teoria do sujeito, geografia e desenvolvimento local. Novos cadernos NAEA, 2005, 8 (2), pp.109-124. https://doi.org/10.5801/ncn.v8i2.54

SEABRA, O. C. de L. Insurreição do uso. In: MARTINS, J. de S. (org.). Henri Lefebvre e o retorno à dialética. São Paulo: Hucitec, 1996.

SCHMID, C. A teoria da produção do espaço de Henri Lefebvre: em direção a uma dialética tridimensional. Geousp, n. 32, 2012, p. 89-109 (Tradução de Marta Inez Medeiros Marques e Marcelo Barreto). https://doi.org/10.11606/issn.2179-0892.geousp.2012.74284

SMITH, N. Desenvolvimento desigual: natureza, capital e a produção do espaço. Rio de Janeiro: Bertrand Brasil, 1988.

SPOSITO, E. S. Geografia e Filosofia. São Paulo: Editora UNESP, 2004.

SPOSITO, E. S. Migracão e permanência das pessoas nas cidades pequenas. Os casos de Pirapozinho e Álvares Machado na Alta Sorocabana. São Paulo: USP/FFLCH, 1983 (Dissertação de Mestrado).

TOURAINE, A. Critique de la modernité. Paris: Fayard, 1992.

TOURAINE, A. El sujeto. Un nuevo paradigma para comprender el mundo de hoy. Buenos Aires: Paidós, 2006.

TUAN, Y.-F. Topofilia: Um estudo da percepção, atitudes e valores do meio ambiente. São Paulo: Difel, 1980. 288p

ZAOUAL, H. O homo situs e suas perspectivas paradigmáticas. OIKOS, Rio de Janeiro, v. 9, n.1, p.13-39, 2010.

Recebido em: 05/07/2020

Aceito para publicação em:26/11/2020 